\title{
MAKNA KEKERABATAN DALAM BUDAYA LONTO LEOK PADA PROSES PILKADA DI MANGGARAI BARAT
}

\author{
${ }^{1}$ Felisianus N. Rahmat, ${ }^{2}$ Benedictus Arnold Simangunsong \\ ${ }^{1}$ Universitas Pelita Harapan \\ 1Email: andrerahmat70@gmail.com \\ 2Univesitas Pelita Harapan \\ 2Email: benedictus.simangunsong@uph.edu
}

\begin{abstract}
Abstrak
Budaya memainkan peran yang sangat penting dalam politik karena menjadi cerminan masyarakat dalam menentukan sikap dan pilihan politik atau membentuk karakteristik masyarakat dalam berpolitik. Contoh dari hubungan antara budaya dan politik bisa tergambarkan pada isu kekerabatan pada pilkada Manggarai Barat 2020 yang dibahas dalam penelitian ini. Fenomena kekerabatan yang dimaksud adalah adanya kecenderungan dari masyarakat Manggarai Barat pada umumnya untuk memilih pemimpin yang seasal atau karena faktor kekerabatan dan kekeluargaan atau dikenal sebagai budaya lonto leok yang masih kuat mempengaruhi kehidupan masyarakat termasuk politik. Penelitian ini menggunakan paradigma interpretif dengan metode penelitian Fenomenologi. Adapun pengumpulan data penelitian dilakukan dengan data primer yaitu melakukan wawancara mendalam dan dokumentasi serta data sekunder berupa studi kepustakaan. Wawancara dilakukan kepada para informan yang melakukan lonto leok menjelang Pilkada Mabar Tahun 2020 dan juga pada pilkada-pilkada sebelumnya. Hasil penelitian menunjukkan bahwa makna kekerabatan dalam budaya lonto leok pada proses pilkada di Manggarai Barat adalah kebersamaan dan ketergantungan. Sementara peran budaya lonto leok dalam proses politik adalah pada saat pengambilan keputusan dan menumbuhkan ikatan kekerabatan.
\end{abstract}

Kata kunci: Budaya, Politik, Kekerabatan, Lonto Leok, fenomenologi, makna kekerabatan

\begin{abstract}
Culture plays a very important role in politics because it reflects the everyday life of society in determining political attitudes and choices or shaping the characteristics of society in politics. One of them many examples about the relationship between culture and politics can be illustrated in the issue of kinship in the 2020 West Manggarai regional election discussed in this study. The kinship phenomenon in question is the tendency of the West Manggarai community in general to choose leaders who are in the same kinship and it is known as the lonto leok culture which still strongly influences people's life, including politics. This study uses an interpretive paradigm with phenomenological research methods. The research data collection was carried out with primary data, namely conducting in-depth interviews and documentation and secondary data in the form of literature study. Interviews were conducted with informants who conducted lonto leok ahead of the 2020 Mabar Pilkada and also in the previous pilkada. The results showed that the meaning of kinship in the lonto leok culture in the election process in West Manggarai
\end{abstract}


was togetherness and dependence. Meanwhile, the role of lonto leok culture in the political process is at the time of making decisions and fostering kinship ties.

Keywords: Culture, Politics, Kinship, Lonto Leok, phenomenology, meaning of kinship

\section{Pendahuluan}

Pada setiap pertarungan politik, tentunya ada banyak aspek yang dapat mempengaruhi masyarakat dalam menentukan pilihan politik atau perilaku memilih. Sebagaimana menurut pandangan Bartles dan Roth bahwa pilihan politik atau perilaku memilih dari masyarakat dapat ditinjau berdasarkan tiga pendekatan yaitu sosiologis, psikologis dan rasional (Harianto, 2014). Pendekatan sosiologis menjelaskan tentang adanya peran dari nilai-nilai sosiologis dari masyarakat seperti agama, budaya, etnis tertentu, kelas sosial, faktor keluarga dan sebagainya dapat mempengaruhi masyarakat dalam menentukan pilihan politik. Pendekatan selanjutnya adalah psikologis terkait dengan pilihan politik yang disebabkan oleh dorongan atau keterikatan secara psikologis. Sementara pendekatan rasional berkaitan dengan pemilih rasional yang memperhatikan berbagai aspek dalam menentukan pilihanya tidak hanya sosiologis dan psikologis tetapi juga aspek rekam jejak, program kerja yang ditawarkan, visi dan misi, resiko yang akan diterima, orientasi pada hasil yang akan dicapai dan sebagainya.

Berangkat dari ketiga pendekatan yang telah dijelaskan di atas, maka pendekatan sosiologis dianggap memiliki hubungan dengan penelitian ini karena berupaya membahas keberadaan budaya suatu masyarakat dalam mempengaruhi pilihan politik. Tentunya ada banyak fenomena politik yang sudah terjadi untuk menggambarkan hubungan budaya dan politik. Salah satunya adalah pemilihan umum kepala daerah (pilkada) di Daerah Khusus Ibukota (DKI) tahun 2017. Pilkada DKI tahun 2017 merupakan gelaran pemilu yang memanfaatkan isu politik identitas (agama dan etnis) sebagai strategi untuk menarik simpati dan dukungan dari masyarakat Jakarta (Lestari, 2019).

Strategi yang dilakukan pasangan Anis dan Sandi, sebagaimana yang disampaikan Hanta Yuda, diwujudkan melalui tutur kata yang santun, bahasa keagamaan serta berpakaian yang menunjukkan identitas dari suatu kelompok masyarakat tertentu yaitu para pemilih sosiologis. Melalui strategi tersebut pasangan Anies dan Sandi ingin merepresentasikan diri sebagai bagian dari kelompok yang sosiologis (Florene, 2017). Pada akhirnya, hasil yang diperoleh adalah pasangan Anis Baswedan dan Sandi Uno kala itu mampu mengungguli rivalnya dengan perolehan suara 3.240.332 yaitu sekitar 57. 95\% dari total keseluruhan suara pemilih (Lestari, 2019). Perolehan suara dari pasangan tersebut cukup menggambarkan bahwa strategi politik agama dan identitas yang dikonstruksikan oleh elit politik atau tim pendukung Anis dan Sandi berhasil karena memang masyarakat di DKI kala itu, memilih pemimpin karena faktor kesamaan agama dan etnis atau daerah asal yang sama.

Selain isu agama dan etnis, terdapat juga isu lainnya yang kerap muncul dalam setiap pelaksanaan pilkada di Indonesia, yaitu politik kekerabatan. Politik kekerabatan menjadi salah satu fenomena yang marak terjadi yang memperlihatkan adanya pertimbangan faktor kekerabatan dalam menentukan dan memilih kandidat yang maju 
di pilkada. Umumnya, calon kepala daerah yang diusung adalah orang-orang yang memiliki hubungan kekerabatan dan kekeluargaan dengan pejabat petahana. Hal tersebut dapat dibuktikan dalam beberapa kontestasi pilkada yang sudah digelar di Indonesia selama ini, seperti: pilkada Lampung Barat tahun 2017, kabupaten Gowa dan Klaten tahun 2015, pilkada Bantul dan Kendal tahun 2010 (Aritonang, 2013). Serta yang paling fenomenal dan dikenal luas oleh publik adalah politik kekerabatan yang dipertontonkan oleh Ratu Atut, mantan gubernur Banten dan keluarganya yang mampu menguasai hampir sebagian wilayah banten dengan menjadi kepala daerah dalam beberapa periode di berbagai kabupaten dan kota di wilayah Banten (Wirawan, 2015).

Adapun sebelumnya, fenomena-fenomena politik kekerabatan dalam kontestasi pilkada juga sudah banyak diteliti. Misalnya, penelitian tentang politik kekerabatan sudah banyak dilakukan yaitu penelitian dari Pamungkas (2018), Rusnaedy dan Purwaningsih (2018), Putri (2017) yang membahas mengenai praktek politik kekerabatan dalam mengusung pasangan calon yang akan maju di Pilkada di beberapa daerah di Indonesia. Calon yang diusung memiliki hubungan kekerabatan atau kekeluargaan dengan kepala daerah yang berkuasa sebelumnya. Dari penelitian yang mereka lakukan dapat diketahui bahwa calon kepala daerah yang diusung melalui praktek politik kekerabatan dianggap memiliki peluang yang besar untuk menang dibandingkan pasangan lainnya. Calon yang memiliki hubungan kekerabatan memiliki modal yang kuat serta memanfaatkan hubungan tersebut untuk menggalang dukungan dari berbagai pihak.

Selain itu, terdapat juga penelitian serupa lainnya dilakukan Purwaningsih (2015) yang mengkaji tentang fenomena politik kekerabatan dalam proses rekruitmen pada beberapa partai politik yaitu partai Golkar, Partai Amanat Nasional (PAN) dan Demokrat di daerah Sulawesi Selatan tahun 2009. Pada tahun yang sama, Purwaningsih juga meneliti tentang praktek politik kekerabatan dan dampaknya terhadap kualitas yang dimiliki oleh kandidat. Dalam artikelnya dijelaskan semakin mudah seseorang memperoleh jabatan akibat politik dinasti maka indeks kualitasnya cenderung menurun. Jadi secara umum beberapa penelitian di atas membahas mengenai praktek politik kekerabatan atau dinasti politik pada tataran lembaga, organisasi, partai politik atau institusi pemerintahan yang masih ada hingga saat ini serta pengaruhnya terhadap jalannya kontestasi politik lokal dan pemerintahan di beberapa wilayah di Indonesia.

Senada dengan penelitian-penelitian di atas, peneliti menyadari bahwa praktek politik kekerabatan di Indonesia sulit dihindari dan masih terus menggerogoti setiap kontestasi politik di tingkat lokal maupun secara nasional, pada lembaga pemerintahan, partai politik dan sebagainya. Fenomena politik kekerabatan acap kali terjadi karena proses kaderisasi di partai politik yang berjalan buruk sehingga dalam memilih dan mengusung kandidat tidak melalui proses seleksi untuk mencari sosok yang berkualitas. Di sisi lain, praktek ini menurut Putri (2017) terjadi karena adanya keinginan yang kuat untuk mempertahankan kekuasan bagi golongan tertentu baik di partai politik maupun di lembaga pemerintahan. Berdasarkan uraian-uraian di atas, peneliti kemudian berupaya membahas fenomena kekerabatan pada kontestasi pilkada dalam penelitian ini. Namun pembahasan mengenai fenomena kekerabatan berkaitan dengan kecenderungan dari masyarakat Manggarai pada umumnya untuk memilih pemimpin yang seasal atau karena faktor kekerabatan dan kekeluargaan. Hal itu 
dibuktikan melalui survey yang dilakukan oleh Lembaga Aeropagus yang dimuat dalam IndonesiaSatu.co, 12 Mey 2017 menjelang pemilihan gubernur (pilgub) NTT 2018 yang menjelaskan bahwa mayoritas pemilih di Manggarai cenderung memilih calon pemimpin yang seasal, karena faktor kekerabatan atau kekeluargaan. Tidak hanya itu, kecenderungan pilihan politik pada masyarakat Manggarai muncul tidak terlepas dari eksistensi dan peran budaya lonto leok dalam kehidupan masyarakat, dimana budaya tersebut menjadi faktor pertimbangan bagi masyarakat dalam menentukkan pemimpin yang dipilih.

Untuk itu, penelitian ini nantinya fokus pada makna kekerabatan dalam budaya lonto leok pada proses pilkada di Manggarai Barat. Selanjutnya peneliti juga ingin menggali tentang peran budaya tersebut dalam proses politik di Mabar. Konteks kekerabatan ini nantinya akan dilihat dalam aktivitas budaya lonto leok menjelang perhelatan pilkada yang berlangsung di kabupaten Manggarai Barat tahun 2020 serta pilkada-pilkada yang sudah dilaksanakan sebelumnya.

\section{Tinjauan Pustaka}

Untuk memberikan gambaran mengenai bagaimana budaya dan politik saling terikat, maka peneliti menjelaskan melalui Teori interaksi simbolik yang diperkenalkan oleh George Herbert Mead, seorang konstruktionis awal. Dalam pembahasannya, Mead awalnya menggunakan istilah interaksionisme simbolis untuk menjelaskan bahwa "our thoughts, self concept and the wider community we leave in are created through communication" (Griffin, 2019, h.53). Cara kita sebagai manusia berpikir dan bertindak dipengaruhi oleh makna yang diberikan kepada orang lain, suatu peristiwa dan benda. Makna tersebut dibentuk melalui bahasa yang digunakan ketika kita berkomunikasi dengan orang lain. Perhatian utama dari interaksionionisme simbolis kata Mead tertuju pada manusia yang senantiasa berinteraksi dengan orang lain dalam keseharian hidupnya (Littlejohn \& Foss, 2012). Manusia juga secara bersama-sama berbagi pemahaman dan pengertian terkait tindakan-tindakan tertentu dan bahasa-bahasa yang digunakan. Berdasarkan pandangan tersebut, teori interaksi simbolik kemudian tidak hanya fokus terhadap apa yang dibicarakan saja tetapi juga bahasa dan gesture seseorang dalam mengantisipasi cara orang lain merespon. Jadi inti dari pandangan Mead ini adalah proses pembentukan realitas sosial tergantung bagaimana cara kita berpikir, konsep diri, komunikasi serta interaksi sosial yang terjalin. Selain itu, pandangan Mead juga bisa dimaknai bahwa realitas sosial dibentuk melalui percakapan antara individu-individu dalam kelompok masyarakat.

Blummer kemudian menambahkan bahwa "symbolic interaction isn't just talk. The term refers to the language and gestures a person uses in anticipation of the way others will respond" (Griffin, 2019, h.53). Pandangan tersebut menegaskan bahwa teori interaksi simbolik merupakan sebuah proses pemaknaan secara terus menerus atau berkelanjutan saat percakapan berlangsung terhadap bahasa dan gerak tubuh (gesture) dalam menghadapi antisipasi bagaimana reaksi orang lain. Pandangan lain juga dikemukakan oleh Scott Plungkett mengatakan bahwa teori interaksi simbolik berbicara tentang cara manusia menginterpretasi dan mengartikan sesuatu atau cara manusia memaknai dunianya melalui interaksinya dengan orang lain dalam (Haris \& Amalia, 2018). Sementara dalam pemikiran LaRosa dan Donald C. Ritzes seperti dikutip dalam Siregar (2011) sebagai membentuk dunia simbolik secara bersama. Pembentuk 
simbol itu sendiri merujuk pada suatu proses komunikasi yang pemaknaannya bergantung pada pemahaman terhadap tindakan orang lain melalui bahasa, gesture dan penggunaan simbol - simbol serta interpretasi.

Pembentukan simbol bersama dalam sebuah interaksi seperti dikutip dari West \& Turner (2008) terdapat tiga tema utama yang memperlihatkan tentang interaksi simbolik tersebut yakni pertama, makna tidak bersifat intrinsik terhadap apa pun tetapi melalui penciptaan interpretasi di antara individu- individu yang menciptakan makna. Tema kedua, pentingnya konsep diri. Pada tema ini titik penekanan dari teori interaksi simbolik terletak pada pentingnya suatu konsep diri individu atau terkait dengan seperangkat pandangan yang relatif stabil yang diyakini orang tentang dirinya. Tema ini kemudian sejalan dengan asumsi yang dikemukakan oleh LaRosa dan Reitzes yaitu manusia mengembangkan konsep diri melalui interaksinya dengan orang lain dan konsep diri dapat melahirkan motif penting bagi perilaku (West \& Turner, 2008). Tema ketiga, Hubungan antara individu dan masyarakat. Tema ini menyatakan bahwa perilaku individu dibatasi oleh adanya norma-norma sosial, namun pada akhirnya individu yang berperan sendiri untuk menentukan pilihan yang terdapat dalam sosial kemasyarakatannya. Tema ini memiliki dua asumsi penting yaitu manusia dan kelompok masyarakat dipengaruhi oleh proses sosial dan budaya, struktur sosial dihasilkan dalam interaksi sosial.

Sehingga seperti dikatakan oleh G. Almond, S.Verba \& L. W. Pye dalam Alamsyah (2010) setiap proses politik selalu terjadi dalam konteks budaya tertentu. Selain itu, setiap proses politik diyakini selalu berhubungan langsung dengan budaya dari suatu masyarakat. Sehingga budaya kemudian menjadi cerminan masyarakat dalam menentukan sikap dan pilihan politik atau membentuk karakteristik masyarakat dalam berpolitik. Namun sebelum membahas lebih jauh mengenai relevansi antara keduanya, terlebih dahulu harus memahami pengertian dari budaya dan politik itu sendiri.

Karena itu apabila dikaitkan dengan kekerabatan sebagai sebuah budaya dan proses politik, seperti dikatakan oleh Purwaningsih dalam Putri (2017) memberikan pemahaman mengenai politik kekerabatan sebagai aktivitas politik yang mempertimbangkan faktor kekeluargaan (garis keturunan atau karena ikatan perkawinan) dalam proses rekruitmen untuk menduduki jabatan pemerintahan atau politik tanpa mempertimbangkan faktor kemampuan yang dimiliki atau mengabaikan prosedur yang sebenarnya

\section{Metode Penelitian}

Penelitian ini menggunakan paradigma interpretif dan metode fenomenologi. Teknik pengumpulan data yang digunakan peneliti adalah wawancara secara mendalam (in depth interview) dengan informan yang terdiri atas anggota masyarakat, tim sukses, tua adat dan tokoh masyarakat yang diketahui sudah melakukan kegiatan lonto leok menjelang pelaksanaan pilkada di Mabar tahun 2020 dan juga pilkadapilkada sebelumya. Analisis data yang digunakan adalah teknik coding (pengodean). Teknik coding menurut Straus \& Corbin terdiri atas pengodean terbuka, pengodean berporos dan pengodean selektif (Gunawan, 2017). Proses analisis dilakukan dengan cara mengelompokkan data terlebih dahulu, menyusunya ke dalam berbagai kategori/klasifikasi tertentu, membuat kategorisasi data serta melakukan seleksi 
terhadap data-data secara sistematis. Sehingga dapat diketahui data-data yang sesuai dan tidak sesuai dengan penelitian.

\section{Hasil Penelitian}

\section{Makna Politik Kekerabatan Dalam Budaya Lonto Leok Kebersamaan}

Kebersamaan dalam penelitian ini dimaknai sebagai sebuah bentuk kolektivitas di dalam masyarakat, dimana kolektivitas tersebut digambarkan sebagai sebuah kesamaan pandangan, pemahaman, serta sikap dalam berpolitik. Kesamaan-kesamaan tersebutlah yang pada akhirnya mendorong anggota masyarakat menempatkan kepentingan umum lebih tinggi dibandingkan kepentingan pribadi. Kepentingan umum itu antara lain adalah keputusan sebagai asas kesepakatan bersama, kebersamaan sebagai semangat untuk selalu bersatu, bergandengan tangan.

Temuan tersebut diperkuat dengan pernyataan dari Pandor seperti dikutip dalam Riyanto, Mulyatno \& Madung (2015) bahwa," kebersamaan sebagai suatu kehidupan yang menekankan prinsip persatuan, persaudaraan dan gotong royong di antara sesama anggota masyarakat dalam kesehariannya. Setiap warga kemudian memiliki tanggung jawab atas kehidupan bersama di masyarakat". Dalam ungkapan Manggarai seperti diungkapkan oleh Pandor (Riyanto, Mulyatno \& Madung, 2015) "muku ca pu'u neka woleng curup, teu ca ambong neka woleng lako; ema agu anak neka woleng curup, weta agu nara neka woleng bantang artinya pisang satu pohon tidak boleh beda pembicaraan, tebu serumpun tidak boleh beda jalan, bapa dan anak tidak boleh beda tutur, saudari dan saudara atau adik dan kakak tidak boleh berbeda pandangan"

Sedangkan dalam konteks politik, misalnya tergambarkan dalam gelaran pemilu masyarakat akan berunding bersama untuk menentukan siapa kandidat yang akan dipilih. Menurut tokoh masyarakat yang menjadi informan penelitian ini, apa yang sudah disepakati dalam pertemuan harus dipatuhi oleh semua yang hadir, tidak ada ruang lagi bagi pendapat-pendapat lain di luar kesepakatan bersama. Hal serupa dipertegas oleh anggota masyarakat bahwa putusan-putusan saat pertemuan selalu berdasarkan kesepakatan bersama. Kebersamaan dalam politik atau demokrasi juga menurut Itok (2017) bagi masyarakat Manggarai juga tertuang dalam ungkapan "nakeng ca wae neka woleng tae", artinya ikan yang ada dalam satu sungai tidak boleh beda kata. Ungkapan ini menekankan prinsip kesamaan kata, yakni kalau sudah disepakati untuk memilih salah satu kandidat, maka kesepakatan itu yang harus dipegang oleh masing-masing anggota masyarakat, tidak boleh ada lagi pilihan lain.

\section{Ketergantungan}

Konsep ketergantungan dalam penelitian ini bisa dilihat dalam dua aspek. Pertama, ketergantungan sosial yaitu suatu hubungan yang memperlihatkan bahwa anggota masyarakat saling membutuhkan satu sama lain dalam kesehariannya. Ketergantungan di sini menggambarkan bahwa masyarakat selalu mementingkan kebersamaan dalam hidup yaitu selalu bergandengan tangan dalam hal apa pun, saling membantu, peduli satu sama lain serta berusaha untuk menyelesaikan persoalan secara bersama melalui musyawarah mufakat dalam lonto leok. Adanya ketergantungan tersebut kemudian menegaskan kodrat manusia sebagai makhluk sosial (ens sociale) 
yang selalu membutuhkan orang lain. Sebagaimana menurut Roucek \& Waren yang mengatakan bahwa saling tergantung satu sama lain menegaskan identitas masyarakat di desa atau kampung masih terikat satu sama lain, cenderung memiliki sikap dan tingkah laku yang sama, budaya yang diakui secara bersama dan menjaga hubungan yang erat dengan sesama (Susilawati, 2012), contohnya saat kandidat datang berkunjung tua adat akan mengundang seluruh anggota masyarakat untuk duduk bersama untuk membicarakan segala sesuatu yang dibutuhkan, hal-hal apa saja yang perlu dipersiapkan melibatkan banyak orang untuk mengambil keputusan baik itu tentang siapa pemimpin yang dipilih maupun terkait pembangunan di kampung.

Kedua, ketergantungan akan budaya adalah suatu realitas di masyarakat yang menempatkan budaya lonto leok pada posisi yang penting. Lonto leok tidak hanya mengatur kehidupan masyarakat tetapi juga mengajarkan nilai-nilai kehidupan yang harus dihayati oleh semua anggota masyarakat, seperti kekeluargaan, persatuan, tolong menolong, cara bertutur kata dan bersikap serta berusaha untuk selalu seia sekata dan melangkah bersama. Dari hasil penelitian, lonto leok menjadi cerminan bagi masyarakat dalam menentukan pilihan politik. Cerminan yang dimaksudkan di sini adalah lonto leok menjadi wadah bagi seluruh masyarakat untuk membahas dan menyepakati bersama tentang pandangan politik ke depannya, siapa kandidat yang akan dipilih atau programprogram prioritas bersama untuk diusulkan kepada kandidat artinya saat duduk bersama orang-orang Manggarai tidak lagi membahas kepentingan politik pribadinya melainkan kepentingan politik secara umum di kampung yang bisa dikatakan sebagai wujud dari musyawarah untuk mufakat.

\section{Peran Budaya Lonto Leok Dalam Proses Politik Di Masyarakat Peran Budaya Lonto Leok Dalam Pengambilan Keputusan}

Peran Budaya Lonto Leok dalam pengambilan keputusan secara politik mempunyai pengaruh yang sangat kuat, sangat berpengaruh dan sifatnya adalah menghidupinya keharmonisan hidup bersama. Sehingga dapat dikatakan bahwa peran budaya lebih tinggi dibandingkan politik. Salah satu penggambaran mengenai bagaimana peran budaya sangat berpengaruh terlihat dalam pengambilan keputusan bersama adalah keputusan yang mengikat seluruh anggota masyarakat karenanya salah satu cara untuk pembuatan keputusan tersebut adalah duduk bersama di rumah adat (mbaru gendang). Seperti digambarkan oleh Edison (2015) adalah bantang cama reje leleng yang artinya memutuskan secara bersama-sama. Seluruh anggota masyarakat akan dilibatkan dan melalui kegiatan duduk bersama di dalam rumah adat semua pandangan diutarakan, dibahas dari berbagai sudut pandang untuk kemudian mencapai keputusan bersama.

Prinsip tersebut secara jelas tergambar dalam tahapan yang dijalankan selama lonto leok berlangsung yaitu caca, cica dan congko (Riyanto, Mulyatni \& Madung, 2015). Pertama, caca dipahami sebagai bagian dari proses membongkar dan membahas bersama persoalan yang sedang dihadapi bersama. Terkait kajian ini, caca dilihat sebagai suatu proses penyampaian pesan politik oleh calon kepala daerah kepada tua adat dan seluruh masyarakat yang hadir untuk dibahas bersama. Penyampaian pesan ini biasanya berupa rencana sang calon untuk maju di pilkada dan meminta restu dari masyarakat serta menyampaikan visi dan misinya di hadapan seluruh anggota masyarakat yang hadir. Kedua, cica berarti memberikan tanggapan terkait persoalan 
yang dibahas. Dalam lonto leok semua diberi ruang untuk mengemukakan pendapat. Misalnya dalam kajian ini, cica adalah saat dimana masyarakat menanggapi pesan yang disampaikan calon, memberikan masukan serta menyampaikan aspirasi untuk kemudian dijadikan bahan pertimbangan ke depannya seandainya nanti terpilih.

Ketiga, congko diartikan sebagai tahapan untuk menyelesaikan, membereskan atau menyimpulkan persoalan atau hal-hal yang sudah dibahas dalam lonto leok. Jadi bisa dikatakan bahwa caca, cica dan congko dalam lonto leok merupakan proses musyawarah untuk mencapai mufakat yang dilakukan masyarakat Manggarai saat menyikapi persoalan yang dihadapi, termasuk bidang politik. Proses tersebut juga memperlihatkan bahwa pengambilan keputusan dilakukan secara kolektif saat proses adat di dalam rumah adat. Edison (2015) kemudian mengungkapkan bahwa mbaru gendang (rumah adat) adalah simbol yang mempersatukan serta pusat dari seluruh kehidupan masyarakat Manggarai.

Pandangan serupa juga disampaikan oleh Pranamantara (2014) simbol-simbol yang ada di dalam rumah adat menegaskan falsafah hidup orang Manggarai yang mengedepankan rasa persatuan dan kesatuan serta prinsip musyawarah mufakat dalam menyelesaikan berbagai persoalan. Dalam proses pilkada misalnya, lonto leok dalam rumah adat tidak hanya dipandang sebagai forum untuk kumpul bersama, tetapi juga dimaknai sebagai aktivitas masyarakat untuk membahas dan memutuskan siapa yang terbaik dan layak menjadi pemimpin di masa mendatang. Tentunya kriteria yang dipilih harus selaras dengan harapan dan cita-cita seluruh anggota masyarakat.

Oleh karena itu setiap event-event politik di daerah Manggarai, upacara lonto leok selalu dilakukan baik antara sesama masyarakat di kampung maupun antara masyarakat dengan kandidat yang ingin maju di pilkada. Politik kemudian menurut pandangan Tuname (2017) sangat dekat dengan masyarakat, maka dari itu budaya lokal harus menjadi pijakan dalam berpolitik. Sehingga tidak mengherankan jika banyak politisi masuk di suatu kampung mencari simpati masyarakat melalui pendekatan adat. Sejalan dengan pernyataan tersebut, tim sukses yang menjadi informan mengatakan bahwa budaya menjadi suatu kesatuan yang utuh dengan proses politik. Tim menyadari betul bahwa pola pendekatan budaya masih relevan hingga saat ini. Hal itu terjadi karena lonto leok merupakan kearifan lokal yang menjadi penuntun masyarakat dalam segala hal tidak hanya dalam politik.

\section{Peran Budaya Lonto Leok Dalam Menumbuhkan Ikatan Kekerabatan}

Selain mempengaruhi pengambilan keputusan politik, lonto leok sebagai sebuah budaya juga berperan dalam menumbuhkan ikatan kekerabatan di antara anggota masyarakat dengan kandidat yang hadir, artinya kita bisa katakan bahwa perilaku politik dibalut dalam proses budaya. Dalam penelitian ini, konsep kekerabatan merupakan suatu hubungan yang terjalin antara anggota masyarakat dengan orang lain yang berasal dari luar kampungnya. Hubungan tersebut sangat memperhatikan aspek kekeluargaan, garis keturunan, asal kampung dan suku antara orang luar dengan masyarakat.

Sebagaimana menurut Anggariani (2013) kekerabatan berarti suatu relasi yang terjadi di antara masyarakat berdasarkan kekeluargaan. Hal senada juga dikemukakan oleh Lery (2016) kekerabatan merupakan hubungan sosial karena adanya ikatan kekeluargaan, perkawinan, garis keturunan, kesamaan suku dan budaya. Aspek-aspek 
tersebut nantinya akan ditelusuri dan diputuskan secara bersama oleh tua adat sebagai pemimpin di satu kampung, tokoh dan anggota masyarakat melalui proses lonto leok.

Artinya saat lonto leok, hal-hal seperti asal usul keluarga, suku dan latar belakang dari orang lain tersebut nantinya ditelusuri bersama apakah hubungan tersebut memang ada atau tidak. Jika hubungan itu ada maka kemungkinan kekerabatan dapat terjalin, sebaliknya jika tidak memenuhi aspek-aspek di atas maka kekerabatan tidak dapat terjalin.

Oleh karena itu, seseorang yang ingin mencalonkan diri pada pilkada Manggarai Barat pada tahun 2020 harus menjalin kekerabatan dengan masyarakat melalui pendekatan budaya agar memperoleh dukungan politik. Jadi di sini kekerabatan seperti dikatakan oleh Siswanto (2014) memiliki tujuan politik yang ingin dicapai baik secara pribadi maupun kelompok. Sebagaimana menurut pandangan Smith seperti dikutip dalam Eliza (2015) bahwa kekerabatan dimaknai sebagai sebagai suatu hubungan yang terjadi antara indvidu dan orang lain untuk memperoleh suatu kedekatan yang bisa bermanfaat, melalui bahasa, simbol adat yang mencerminkan kekerabatan itu sendiri. Karena itu semua yang ada dalam upacara budaya tersebut harus menggambarkan bahwa tuan rumah dan tamu adalah saudara dan keluarga yang dipersatukan. Makanya proses komunikasi dan interaksi selama lonto leok berlangsung harus dapat mencirikan kekerabatan. Selain itu terdapat juga proses komunikasi dan interaksi.

\section{Simpulan}

Makna kekerabatan dalam budaya lonto leok pada proses pilkada di Manggarai Barat adalah adanya kebersamaan dengan semangat yang ditonjolkan adalah persaudaraan, kekeluargaan dan persatuan dalam menyelesaikan segala persoalan di masyarakat dan saling ketergantungan di antara sesama anggota masyarakat dalam berpolitik untuk menentukan pemimpin yang akan dipilih dengan tujuan mempersatukan dan memperkokoh persaudaraan di antara sesama masyarakat. Sehingga dapat dikatakan bahwa semua orang Manggarai diharapkan untuk selalu satu pandangan dan pemahaman, satu sikap dan perbuatan serta tidak boleh jalan terpisah melainkan harus selalu berdampingan, inilah kemudian yang dilihat sebagai sebuah keterhubungan antara budaya dan politik.

Selain itu budaya lonto leok juga memiliki peran penting dalam proses politik di Manggarai Barat yaitu saat pengambilan keputusan serta dapat menumbuhkan ikatan kekerabatan antara anggota masyarakat di suatu kampung dengan kandidat yang hadir, seperti adanya ikatan kekeluargaan, perkawinan, garis keturunan, kesamaan suku dan budaya, ketika sudah duduk bersama maka yang ada dalam lingkaran tersebut pada prinsipnya adalah satu keluarga dan bersaudara semuanya.

\section{Daftar Pustaka}

Griffin. 2019. A First Look At Communication Theory. New York: McGraw Hill Education.

Gunawan Imam. 2017. Metode Penelitian Kualitatif Teori dan Praktik. Jakarta: PT. Bumi Aksara 
Hkimat, Mahi. 2018. Kampanye Jitu Dalam Pilkada. Perspektif Komunikasi Politik Pada Masyarakat Jawa Barat. Bandung: Jaringan Peduli Demokrasi

Littlejohn, W S \& Foss, A K. 2009. Teori Komunikasi. Theories of Human Communication. Ed. 9. Jakarta: Salemba Humanika.

Moleong, Lexy J. Metode Penelitian Kualitatif. Ed. Revisi. Bandung: PT. Remaja Rosdakarya.

Pureklolon.Thomas. 2016. Komunikasi Politik Mempertahankan Integritas Akademisi, Politikus dan Negawaran. Jakarta: Gramedia

Riyanto A. Ohoitimur J, Mulyatno \& Madung G, O. 2015. Kearifan Lokal Pancasila. Butirbutir Filsafat KeIndonesian. Yogyakarta: Kanisius

Sugiyono. 2014. Memahami Penelitian Kualitatif. Bandung: CV Alfabeta.

West \& Turner. 2008. Pengantar Ilmu Komunikasi. Analisis dan Aplikasi. Ed. 3. Jakarta: Salemba Humanika.

\section{Jurnal}

Ahmadi Dadi.2008. Interaksi Simbolik. Suatu Pengantar. Jurnal Mediator. Vol 9, No 2 (301-316)

Anggariani Dewi. 2013. Politik Kekerabatan. Makasar: UIN Alaudin. Vol. 2, No 2 (1-8)

Bosco, F H. 2016. Keefektivan Bimbingan Kelompok Berbasis Nilai-nilai Budaya Lonto Leok dalam Meningkatkan Kecerdasan Interpersonal. Ruteng: STKIP Vol 8, No 1 (104-11)

Hasbiansyah. 2008. Pendekatan Fenomenologi: Pengantar Praktik Penelitian dalam Ilmu Sosial dan Komunikasi. Bandung: Mediator, Jurnal Komunikasi Unisba, (163-180)

Haris, A \& Amalia, A. 2018. Makna dan Simbol Dalam Proses Interaksi Sosial. Riau: Jurnal Risalah-Universitas Muhamadiyah Riau. Vol 29, No 1 (16-19)

Haryanto. 2014. Kebangkitan Party ID. Analisis Perilaku Memilih Dalam Politik Lokal di Indonesia. Jurnal Ilmu Sosial dan Ilmu Politik. Vol 17, No 3 (291-3018)

Kurniawan, I. 2016. Budaya Lonto Leok Dalam Langgan Demokrasi. (Kajian Fenomenologis Budaya Lonto Leok Sebagai Strategi Komunikasi Politik. Kupang: Undana

Lestari, Dina. 2019. Pilkada DKI Jakarta 2017: Dinamika Politik Identitas di Indonesia. Surabaya: Universitas Airlangga

Pamungkas. 2018. Politik Kekerabatan di Pilkada: Studi Kasus Terpilihnya Pasangan Calon Hj. Sri Hartini dan Hj. Sri Mulyani pada Pilkada Klaten Tahun 2015. Universitas Diponegoro, (1-16)

Purwaningsih Titin. 2015. Politik Kekerabatan dalam Politik Lokal di Sulawesi Selatan pada Era Reformasi (studi tentang rekruitmen politik pada partai Golkar, PAN dan Demokrat Sulawesi Selatan tahun 2009). Yogyakarta: Jurnal politikFISIPOL-Universitas Muhamadiah Yogyakarta, (1-90)

Purwaningsih. 2015. Politik Kekerabatan dan Kualitas Kandidat Di Sulawesi Selatan. Yogyakarta: Jurnal politik-FISIPOL-Universitas Muhamadiah Yogyakarta, (97123) 
Putri, S A. 2019. Politik Kekerabatan Dalam Pilkada Lampung Barat (2017): Studi Pada Kemenangan Parosil Mabus. Bandar Lampung: FISIP-Universitas Lampung, (1109)

Rusnaedy \& Purwaningsih. 2018. Keluarga Politik Yasin Limpo Pada Pemilihan Kepala daerah di Kabupaten Gowa tahun 2015. Yogyakarta: Jurnal politik-FISIPOLUniversitas Muhamadiah Yogyakarta, (301-322)

Siregar, S.S.N. 2011. Kajian Tentang Interaksi Simbolik. FISIP-Universitas Medan Area, $(100-110)$

\section{Artikel}

Aritonang, R.Deytri. (2013, Oktober 22). 60 Orang Yang Terlibat Politi Dinasti. Diakses dari:

https://nasional.kompas.com/read/2013/10/18/1850579/60.0rang.yang.Terli bat.Politik.Dinasti?page $=$ all

Edison Hiro. (2015, 30 Desember). Mbaru Gendang Dan Pelestarian Budaya Manggarai. Diakses dari: https://www.floresa.co/2015/12/30/mbaru-gendang-danpelestarian-budaya-manggarai/4/

Eliza.2015. Tinjauan Pustaka. Diakses dari: http://repository.uinsuska.ac.id/6982/3/BAB\%20II.pdf

Florenca Ursula. (2017, Januari 2020). Rappler.com. Mengenal Karakter Pemilih di Pilkada DKI Jakarta. Diakses dari: https://www.rappler.com/indonesia/berita/158905-karakter-pemilih-pilkada

Indonesiasatu.co. (2017, 17 Mey). Survey Pilgub NTT 2018. Mayoritas Netizen Pemilih NTT Cenderung Memilih Pemimpin yang seasal. Diakses dari: http://www.indonesiasatu.co/detail/survei-pilgub-ntt-2018--mayoritasnetizen-pemilih-ntt-cenderung-pilih-kandidat-seasal

Ngaru, H \& Sinir, S. (2020, 13 Juli). NTT PEMBARUAN.Acara adat wuat wai Bacabup Maria Geong dihadiri Bupati Mabar. Diakses dari: https://nttpembaruan.com/2020/07/13/acara-adat-wuat-wai-bacabup-mariageong-dihadiri-bupati-mabar/

Siswanto. (2014, Januari 03) Kekerabatan Politik dan Politisi Korup. Diakses dari: https://nasional.kompas.com/read/2014/01/03/1001539/Kekerabatan.Politik dan.Politisi.Korup?page=all

Tuname Alfred. 2017. Budaya Lokal Dan Politik Di Pilkada.Opini Alfred Tunmae. Diakses dari: www. Florespost.co

Wirawan, Jerome. (2015, Desember 10) Keluarga Ratu Atut Berjaya di Banten. Diakses https://www.bbc.com/indonesia/berita indonesia/2015/12/151210 indonesi a politik banten 